\title{
Combined pituitary hormone deficiency caused by PROP1 mutations: update 20 years post-discovery
}

Fernanda A. Correa ${ }^{1 *}$, Marilena Nakaguma ${ }^{1 *}$, João L. O. Madeira ${ }^{1 *}$, Mirian Y. Nishi', Milena G. Abrão', Alexander A. L. Jorge'2, Luciani R. Carvalho', Ivo J. P. Arnhold' ', Berenice B. Mendonça'

\begin{abstract}
The first description of patients with combined pituitary hormone deficiencies (CPHD) caused by $P R O P 1$ mutations was made 20 years ago. Here we updated the clinical and genetic characteristics of patients with PROP1 mutations and summarized the phenotypes of 14 patients with 7 different pathogenic PROP1 mutations followed at the Hospital das Clínicas of the University of Sao Paulo. In addition to deficiencies in GH, TSH, PRL and gonadotropins some patients develop late ACTH deficiency. Therefore, patients with PROP1 mutations require permanent surveillance. On magnetic resonance imaging, the pituitary stalk is normal, and the posterior lobe is in the normal position. The anterior lobe in patients with PROP1 mutations is usually hypoplastic but may be normal or even enlarged. Bi-allelic PROP1 mutations are currently the most frequently recognized genetic cause of CPHD worldwide. PROP1 defects occur more frequently among offspring of consanguineous parents and familial cases, but they also occur in sporadic cases, especially in countries in which the prevalence of $P R O P 1$ mutations is relatively high. We classified all reported PROP1 variants described to date according to the American College of Medical Genetics and Genomics and the Association for Molecular Pathology (ACMG-AMP) guidelines: 29 were pathogenic, 2 were likely pathogenic, and 2 were of unknown significance. An expansion of the phenotype of patients with PROP1 mutations was observed since the first description 20 years ago: variable anterior pituitary size, different pathogenic mutations, and late development of ACTH deficiency. PROP1 mutations are the most common cause of autosomal recessive CPHD with a topic posterior pituitary lobe. Arch Endocrinol Metab. 2019;63(2):167-74
\end{abstract}

Keywords

PROP1; combined pituitary hormone deficiency; growth hormone deficiency; short stature
1 Unidade de Endocrinologia do Desenvolvimento, Laboratório de Hormônios e Genética Molecular LIM/42, Disciplina de Endocrinologia, Hospital das Clínicas da Faculdade de Medicina da Universidade de São Paulo, São Paulo, SP, Brasil 2 Unidade de Endocrinologia Genética, Laboratório de Endocrinologia Celular e Molecular LIM/25, Disciplina de Endocrinologia, Hospital das Clínicas da Faculdade de Medicina da Universidade de São Paulo, São Paulo, SP, Brasil

* These three authors equally contributed to this work

Correspondence to:

Fernanda de Azevedo Correa Unidade de Endocrinologia do Desenvolvimento, Laboratório de Hormônios e Genética Molecular LIM/42, Hospital das Clínicas, Disciplina de Endocrinologia, Faculdade de Medicina da Universidade de São Paulo Av. Dr. Eneas de Carvalho Aguiar, 255 05403-000 - São Paulo, SP, Brasil feracorrea@uol.com.br

Received on Apr/3/2018 Accepted on Mar/12/2019

DOI: 10.20945/2359-3997000000139

\section{INTRODUCTION}

I t has been 20 years since Wei Wu in M.G. Rosenfeld's Research Unit first identified inactivating mutations of the PROPI gene in humans with combined pituitary hormone deficiency (CPHD) (1). Until now this has been the most common genetic cause of CPHD (2). Over the past 20 years, our Unit at the Hospital das Clinicas has contributed significantly to the knowledge of PROPI in CPHD, describing for the first time spontaneous involution of the anterior pituitary and the development of cortisol deficiency (3). We also expanded the spectrum of PROPI mutations (4-6). Here we review the cumulative knowledge of the genetics and clinical presentation of patients with PROPI mutations and describe 14 patients who were followed at a single Brazilian center over the past 20 years.
Spontaneous mouse mutants greatly contributed to our initial understanding of CPHD genetics. The Snell and Jackson mice had GH, prolactin and TSH deficiencies. In the early '90s, mutations in Pitl, which encodes pituitary-specific transcription factor- 1 , were described in these animals $(7,8)$. This finding quickly led to the detection of mutations in the human homologue gene POUIFI (previously known as $P I T I)$ with a similar phenotype $(9,10)$. The Ames dwarf mouse, another spontaneous mutant mouse with a similar phenotype, but without mutations in Pitl, had the genetic cause established a little while later: mutations in a paired-like homeodomain transcription factor termed 'Prophet of Pitl' (Propl) (11). The Ames dwarf phenotype resulted from an apparent failure of initial determination of the Pitl lineage, required for 
the production of $\mathrm{GH}$, prolactin, and $\mathrm{TSH}$, resulting in pituitary dysmorphogenesis and failure to activate Pitl gene expression. These results suggested that a cascade of tissue-specific regulators is responsible for the determination and differentiation of specific cell lineages in pituitary organogenesis (11). Finally, in 1998, Wu and cols. reported 4 families in which CPHD was caused by inactivating mutations of the PROPI gene in an autosomal recessive pattern (1). These mutations in the human PROPI gene resulted in a gene product with impaired DNA binding and transcriptional activation ability. In contrast to individuals with POUIFI mutations, patients with PROPI mutations also had luteinizing hormone $(\mathrm{LH})$ and follicle-stimulating hormone (FSH) deficiencies (1).

PROPI (Prophet of Pitl), located in the long arm of chromosome 5 ( $5 \mathrm{q} 35.3)$, has 3 exons and encodes a 226-amino-acid-paired-like homeodomain transcription factor (Figure 1) (12). In 1998, Cogan and cols. and Deladoëy and cols. reported a high frequency of the c.301_302delAG (also known as c.296_297delAG) deletion in exon 2 of PROPI, which remains the most frequent PROPI mutation $(13,14)$.

\section{CLINICAL CHARACTERIZATION}

Since $\mathrm{Wu}$ and cols. first described CPHD families with homozygosity or compound heterozygosity for inactivating mutations in the PROPI gene, several cases have been reported and more detailed phenotypic characteristics have been described (1).

Patients with PROPI mutations do not have an increased prevalence of birth via breech delivery or frequent complications during gestation (15). At birth, in contrast to patients with congenital CPHD caused by other etiologies, neonates with PROPI defects lack perinatal signs of hypopituitarism. Mean birth weights and lengths are usually within the normal range, while neonatal hypoglycemia and prolonged neonatal jaundice are rare $(15,16)$.

The phenotype usually includes short stature during childhood and a lack of sexual development at puberty. Distinct phenotypes can be found with hormonal deficiencies progressing with age and asynchronously over time, even among individuals carrying the same genotype $(3,17)$.

\section{Hormonal deficiencies}

The impairment of pituitary production usually follows a pattern. GH and TSH deficiencies are usually present at diagnosis, $\mathrm{LH}$ and FSH deficiencies are noted at the onset of puberty, and ACTH deficiency, when it occurs, may develop during follow-up (15).

Short stature is generally the first symptom reported in PROPI patients, probably due to combined GH and TSH deficiencies. Growth failure usually develops within the first year of life (height, $-1.5 \pm 0.9$ SDS at 1.5 years of age) and becomes more prominent later in infancy and early childhood, mainly between the ages of 1.5 and 3 years $(-3.6 \pm 1.3$ SDS at 3 years of age $)$, when parents seek medical assistance $(15,16)$. At diagnosis, the bone age is usually severely delayed (median, 3.3 years) (18).

Although TSH deficiency can present shortly after birth, it usually occurs together or after the onset of GH deficiency and before the age of 20 years (mean age, 6.8 years according to Deladoëy and cols.) $(14,17)$.

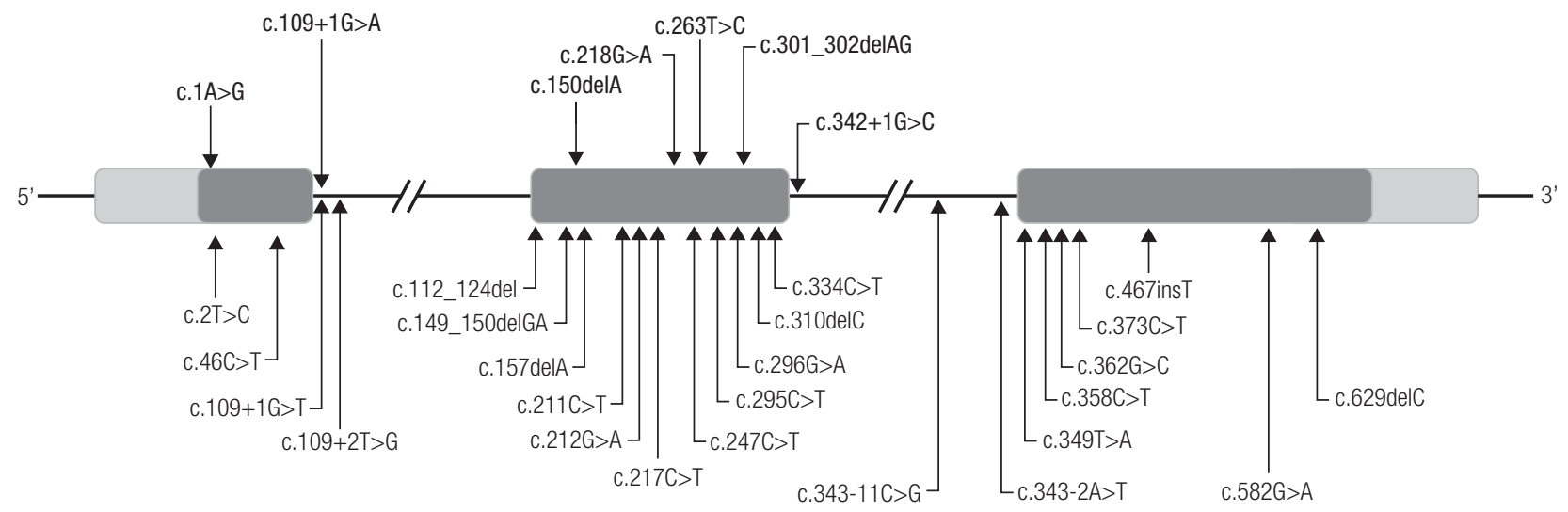

Figure 1. Location of pathogenic variants of the $P R O P 1$ gene. The mutations detected in our cohort are shown in bold type. 
It is important to note that TSH deficiency can be present in patients with an apparently normal TSH-T4 axis. Bottner and cols. diagnosed most cases early in the clinical course based on insufficient responses to thyrotropin-releasing hormone (TRH) stimulation tests; basal TSH levels were within the normal range and free T4 levels were only slightly decreased (15). Hypothyroidism is usually mild in these cases, in contrast to several patients with POUIFI mutations who have severe hypothyroidism and cretinism (19).

Gonadotroph function can also progressively decline and present as a primary or secondary lack of reproductive function. Clinically, it may manifest as a lack of pubertal development, i.e. failure to enter or complete puberty $(14,20)$. There are reports of spontaneous puberty with a posterior decline of gonadotrophic function in Arg120Cys, Phe88Ser, and c.150delA PROPI mutations $(4,17,21)$. Impaired gonadotrophic function occurs in the most common PROPI mutation (c.301_302delAG).

In 1999, Mendonca and cols. reported on an evolving ACTH deficiency in one patient (3). A corticotrophin deficiency was later confirmed in many but not all patients with PROPI deficiency. It appears unlikely that a PROPI transcription factor deficiency directly causes ACTH deficiency, but this clinical finding suggests that PROPI has some role in corticotroph differentiation or viability. Since adrenal function has been shown to gradually decline over time, even after more than four decades, surveillance is extremely important in all patients with PROPI mutations $(20,22,23)$. Furthermore, as GH replacement can increase cortisol metabolism, it is necessary to be aware of the signs of an unveiled adrenal insufficiency (24). The literature review revealed that the mean age at ACTH deficiency diagnosis is 25.3 years (range, 7.467 years), confirming previous data demonstrating the emergence of an ACTH deficiency in the third decade of life $(1,22)$.

Among our 14 patients, 3 were born by cesarean section due to obstetrical indications, the median weight was $3435 \pm 390 \mathrm{~g}$ (SDS $+0.65 \pm 0.92)$; and 2 presented with prolonged neonatal jaundice. Eight of 10 patients for whom term birth weight was available had birthweights according to gestational age above $50^{\text {th }}$ percentile (Fetal Growth Longitudinal Study, World Health Organization) (25). This is similar to another cohort of patients with PROPI deficiency (15). This finding contrasts with that of the majority of patients with GH deficiency of the KIGS database (26). At diagnosis (mean age, 16.3 years), the average bone age delay was -6.0 years. Only 1 patient presented with an isolated GH deficiency, while 7 presented with GH and TSH deficiencies. Six patients started followup at the post-pubertal period; thus, they were already diagnosed with $\mathrm{LH} / \mathrm{FSH}$ deficiency. The remaining patients failed to develop spontaneous puberty; in all cases, puberty was induced with sex steroids. Regarding ACTH deficiency, at the first visit, only one patient had a partial ACTH deficiency (35.8 years). Seven patients evolved to ACTH deficiency (mean age at diagnosis, 28 years, range 11.9-52.1 years) (Table 1 ).

The TRH stimulation test performed in 11 patients showed TSH peak levels of 2.9-6.8 mU/L with abnormal increment $(<5 \mathrm{mU} / \mathrm{L})(3)$. Prolactin levels were more variable with the peak after TRH stimulation (range, $1.5-30.2 \mathrm{ng} / \mathrm{mL}$ ). However, in 7 patients, the prolactin peak was below $6.1 \mathrm{ng} / \mathrm{mL}$. Patients with the highest prolactin peak levels also had the highest TSH peak levels. These findings suggest a pituitary rather than hypothalamic defect.

\section{Neuroimaging}

In patients with PROPI mutations, neuroimaging of the hypothalamic-pituitary region usually shows a hypoplastic or normal anterior pituitary lobe and a topic posterior pituitary lobe, similar to POUIFI patients (27). This contrasts with the majority of patients with CPHD in whom ectopic posterior lobe and other midline defects are commonly detected $(21,28)$.

Changes in pituitary size and morphology can occur over time and were first reported in 1999 (3). An 8.8-year-old girl presented with a diffusely enlarged pituitary gland with a hyperintense signal on Tlweighted magnetic resonance imaging (MRI); the anterior pituitary markedly decreased in size when the patient was 15 years old (height, from $8 \mathrm{~mm}$ to $2 \mathrm{~mm}$ ). An enlarged pituitary gland may be mistaken for a tumor, leading to unnecessary surgery (29). On the other hand, anterior pituitary adenomas have been reported. The surgical removal of the mass revealed an amorphous material but no recognizable cell types on histopathological examination $(3,30)$.

The pituitary can wax and wane in size before undergoing complete involution for reasons yet to be determined (31). Voutetakis and cols. suggested that the mass causing the pituitary enlargement most likely originates from the intermediate lobe $(30)$. This 
enlargement might result from abnormal development of the anterior lobe and the absence of physiological regression of the intermediate pituitary lobe during organogenesis as was demonstrated by Ward and cols. in Ames dwarf mice (32). According to Ward and cols., the basis of the pathogenesis of pituitary lesions in PROPI mutations is the arrest of normal proliferation and migration of the anterior pituitary lobe cells combined with dysmorphic hyperplasia of the dorsal part of the Rathke's pouch.

Among our cohort of 14 patients, MRI showed a hypoplastic anterior pituitary in 11 . The pituitary gland size varied over time from hyperplastic to normal in only 1 patient, while 2 had normal-sized pituitary glands (Table 1). Two patients (patients 11 and 12; Table 1) had pituitary imaging suggestive of microadenomas. Patient 11 presented a small anterior pituitary (height, $3.5 \mathrm{~mm}$ ) with a hypointense nodular area $(3.0 \mathrm{~mm}, \mathrm{Tl}$-weighted MRI). Patient 12 presented a normal anterior pituitary (height, $5 \mathrm{~mm}$ ) with a hypointense area $(3.2 \mathrm{~mm}$, Tl-weighted MRI) suggestive of microadenoma.

\section{GENETIC DIAGNOSIS}

Pathogenic PROPI mutations are the most frequent cause of congenital CPHD, with a prevalence of $0.8-$ $64.8 \%$ in different countries $(2,18)$. In our center, we screened 29 Brazilian index cases with CPHD and topic posterior pituitary lobe; $52 \%(15 / 29)$ of them carried bi-allelic PROPI mutations (5). PROPI defects do not lead to midline defects such as ectopic posterior pituitary lobe (EPP) or septic-optic dysplasia. It is noteworthy that the majority of patients with congenital CPHD present with EPP (2).

PROPI mutations lead to CPHD in an autosomal recessive inheritance pattern; therefore, the prevalence of these mutations is higher in familial cases $(2,5)$. Among our Brazilian cohort of patients with CPHD and topic posterior pituitary lobe, all 6 familial cases presented with PROPI mutations versus only 9 of the 23 sporadic cases (5). Like other recessive genetic disorders, the frequency of PROPI mutations is also higher in patients born to consanguineous parents. In our experience, 5 of 7 sporadic cases born to

Table 1. Clinical features and genetic diagnosis of 14 patients with PROP1 mutation followed at Hospital das Clínicas, University of Sao Paulo Medical School

\begin{tabular}{|c|c|c|c|c|c|c|c|c|c|}
\hline \multirow{3}{*}{ Patient } & \multirow{3}{*}{ Gender } & \multicolumn{4}{|c|}{ First visit } & \multirow{3}{*}{$\begin{array}{c}\text { Birth } \\
\text { weight (g) }\end{array}$} & \multirow{3}{*}{$\begin{array}{l}\text { Final hormone } \\
\text { deficiencies }\end{array}$} & \multirow{3}{*}{$\begin{array}{c}\text { Anterior } \\
\text { pituitary lobe }\end{array}$} & \multirow{3}{*}{$P R O P 1$ variants } \\
\hline & & \multirow{2}{*}{$\underset{\text { (yrs) }}{\mathrm{CA}}$} & \multicolumn{2}{|c|}{ Height } & \multirow{2}{*}{$\begin{array}{c}\text { Bone age } \\
\text { (yrs) }\end{array}$} & & & & \\
\hline & & & $\mathrm{Cm}$ & SD & & & & & \\
\hline 1 & $\mathrm{~F}$ & 4.5 & 92.5 & -3.1 & 2.5 & 3650 & GH, TSH, LH/FSH*, ACTH & Hypoplasia & c.263T>C \\
\hline 2 & $\mathrm{~F}$ & 6.3 & 100.0 & -2.9 & 2.0 & 3420 & GH, TSH, ACTH, LH/FSH* & Normal & c.301_302delAG \\
\hline 3 & $\mathrm{~F}$ & 6.6 & 101.1 & -3.0 & 2.5 & 3780 & $\mathrm{GH}, \mathrm{TSH}, \mathrm{LH} / \mathrm{FSH}^{*}, \mathrm{ACTH}$ & $\begin{array}{l}\text { Hyperplasia/ } \\
\text { hypoplasia }\end{array}$ & c.301_302delAG \\
\hline 4 & $\mathrm{~F}$ & 7.4 & 103.1 & -3.3 & 3.0 & 3550 & $\mathrm{GH}, \mathrm{TSH}, \mathrm{LH} / \mathrm{FSH}^{*}$ & Hypoplasia & C. $1 \mathrm{~A}>\mathrm{G} / \mathrm{c} .263 \mathrm{~T}>\mathrm{C}$ \\
\hline 5 & $\mathrm{~F}$ & 12.3 & 107 & -6.1 & 7.8 & 2500 & $\mathrm{GH}, \mathrm{TSH}, \mathrm{LH} / \mathrm{FSH}^{*}$ & Hypoplasia & c.301_302delAG \\
\hline 6 & $\mathrm{~F}$ & 12.3 & 106.4 & -6.4 & 5.5 & 3700 & GH, TSH, LH/FSH*, ACTH & Hypoplasia & c.301_302delAG \\
\hline 7 & $\mathrm{~F}$ & 14.9 & 104.0 & -9.4 & 2.5 & NA & GH, TSH, LH/FSH, ACTH & Hypoplasia & c.301_302delAG \\
\hline 8 & $\mathrm{~F}$ & 25.8 & 126.5 & -6.0 & 13.0 & 3200 & GH, TSH, LH/FSH & Hypoplasia & PROP1 complete deletion \\
\hline 9 & $\mathrm{~F}$ & 30.3 & 117.2 & -7.5 & 10.0 & NA & GH, TSH, LH/FSH & Hypoplasia & c.301_302delAG \\
\hline 10 & $\mathrm{~F}$ & 35.5 & 119.0 & -7.2 & 13.5 & NA & GH, TSH, LH/FSH, pACTH & Hypoplasia & c.301_302delAG \\
\hline 11 & $\mathrm{~F}$ & 38.2 & 136.1 & -4.4 & - & 2780 & $\mathrm{GH}, \mathrm{TSH}, \mathrm{LH} / \mathrm{FSH}^{*}, \mathrm{ACTH}$ & $\begin{array}{c}\text { Normal/ } \\
\text { microadenoma }\end{array}$ & c. $218 G>A / c .342+1 G>C$ \\
\hline 12 & M & 6.8 & 106 & -2.5 & 2.7 & 3450 & GH, TSH, LH/FSH*, ACTH & $\begin{array}{c}\text { Hypoplasia/ } \\
\text { microadenoma }\end{array}$ & c. $1 \mathrm{~A}>\mathrm{G} / \mathrm{c} .263 \mathrm{~T}>\mathrm{C}$ \\
\hline 13 & M & 9.5 & 97.0 & -6.0 & 3.5 & 3250 & $\mathrm{GH}, \mathrm{TSH}, \mathrm{LH} / \mathrm{FSH}^{*}, \mathrm{ACTH}$ & Hypoplasia & c.301_302delAG \\
\hline 14 & M & 18.3 & 123 & -7.8 & - & NA & GH, TSH, LH/FSH, pACTH & Hypoplasia & c.109+1G>A/c.301_302delAG \\
\hline
\end{tabular}

CA: chronological age; F: female; M: male; TH: target height; NA: not available. * Patients developed LH/FSH deficiency during follow-up. Patient 6 was born preterm; patients 3 and 5 had neonatal jaundice. pACTH: partial adrenocorticotropin hormone deficiency (basal cortisol level $>5.0 \mu \mathrm{g} / \mathrm{dL}$ and peak cortisol level $<18.1 \mu \mathrm{g} / \mathrm{dL}$. 
consanguineous parents presented with PROPI mutations versus only 4 of 16 sporadic cases born to non-consanguineous parents (5).

Different types of molecular defects reportedly disrupt PROPI function, varying from complete gene deletion to frameshift small deletions and insertions and point mutations including missense, nonsense, splicing variants, and mutations affecting the initiation codon (5). Table 2 and Figure 1 summarize all PROPI mutations reported to date.
The majority of PROPI mutations classified as pathogenic according to the American College of Medical Genetics (33) are located on exon 2 and affect the PROPI homeodomain, which is crucial for activating POUIFI expression and pituitary organogenesis (34).

The most prevalent PROPI mutation is the c.301_302delAG (p.Leul02Cysfs*8), which leads to a premature stop codon at residue $110(1,13)$. This frameshift deletion is especially frequent in Eastern Europe, Portuguese, and Latin American patients,

Table 2. PROP1 variants reported to date. Effect on protein and classification according to ACMG guidelines (33). The mutations detected in our cohort are shown in bold type

\begin{tabular}{|c|c|c|c|}
\hline Mutation & Effect on protein & ACMG classification & Reference \\
\hline c. $1 A>G$ & Initiation codon mutation & Pathogenic & (5) \\
\hline c. $2 \mathrm{~T}>\mathrm{C}$ & Initiation codon mutation & Pathogenic & (28) \\
\hline c. $46 \mathrm{C}>\mathrm{T}$ & p.Arg16Ter & Pathogenic & (40) \\
\hline c. $109+1 \mathrm{G}>\mathrm{A}$ & Splicing site change & Pathogenic & (5) \\
\hline c. $109+1 G>T$ & Splicing site change & Pathogenic & (28) \\
\hline c. $109+2 T>G$ & Splicing site change & Pathogenic & (13) \\
\hline c.112_124del & p.Ser38Profs*123 & Pathogenic & (41) \\
\hline c.149_150delGA & p.Gly52Aspfs`58 & Pathogenic & (42) \\
\hline c.150delA & p.Arg53Aspfs*112 & Pathogenic & (36) \\
\hline c.157delA & p.Arg53Aspfs*112 & Pathogenic & (42) \\
\hline c. $211 C>T$ & p.Arg71Cys & VUS & (43) \\
\hline c. $212 \mathrm{G}>\mathrm{A}$ & p.Arg71His & VUS & (43) \\
\hline c. $217 \mathrm{C}>\mathrm{T}$ & p.Arg73Cys & Pathogenic & $(12,44)$ \\
\hline c. $218 \mathrm{G}>\mathrm{A}$ & p.Arg73His & Pathogenic & (45) \\
\hline c. $247 C>T$ & p.GIn83Ter & Pathogenic & (46) \\
\hline c. $263 \mathrm{~T}>\mathrm{C}$ & p.Phe88Ser & Pathogenic & (4) \\
\hline c. $295 C>T$ & p.Arg99Ter & Pathogenic & $(47)$ \\
\hline c. $296 \mathrm{G}>\mathrm{A}$ & p.Arg99GIn & Likely pathogenic & (48) \\
\hline c.301_302delAG & p.Leu102Cysfs*8 & Pathogenic & (1) \\
\hline c.310delC & p.Arg104Glyfs*61 & Pathogenic & (49) \\
\hline c.334C>T & p.Arg112Ter & Pathogenic & (50) \\
\hline$c .342+1 G>C$ & Splicing site change & Pathogenic & (5) \\
\hline c. $343-11 C>G$ & Splicing site change & Likely pathogenic & (49) \\
\hline c. $343-2 A>T$ & Splicing site change & Pathogenic & (12) \\
\hline c.349T>A & p.Phe117lle & Pathogenic & (1) \\
\hline c. $358 \mathrm{C}>\mathrm{T}$ & p.Arg120Cys & Pathogenic & (1) \\
\hline c. $362 G>C$ & p.Arg121Thr & VUS & (51) \\
\hline c. $373 \mathrm{C}>\mathrm{T}$ & p.Arg125Trp & Pathogenic & (49) \\
\hline c.467insT & p.Tyr157Leufs*36 & Pathogenic & $(52,53)$ \\
\hline c. $582 \mathrm{G}>\mathrm{A}$ & p.Trp194Ter & Pathogenic & $(53,54)$ \\
\hline c.629delC & p.Pro210Hisfs`25 (prolonged protein) & Pathogenic & (54) \\
\hline
\end{tabular}

ACMG: American College of Medical Genetics (33); VUS: variant of uncertain significance. 
probably due to two ancestral founder haplotypes: one that originated from the Baltic Sea area around 2525 years ago and another that originated from the Iberian Peninsula around 583 years ago (35). The c.301_302delAG mutation, the most common genetic diagnosis in Brazilian patients with CPHD and topic posterior pituitary, was present in 9 of 15 index patients with PROPI mutations in our group (5).

The second most prevalent mutation is the frameshift 1-bp deletion c.150delA (p.Arg53Aspfs*112) (36), which is probably due to the founder variant that originated from the Belarus region around 1093 years ago (35). Interestingly, we detected this mutation in only one index case in our cohort (5).

Although the known founder effect of the c.301_302delAG mutation in both Portuguese and Spanish populations potentially contributes to a high prevalence of PROPI mutations in our cohort, 6 additional PROPI mutations were identified in our population. The multi-ethnic origin of the Brazilian population (Amerindian, African, various European, and Asian immigrants) may contribute to these findings (5).

The molecular diagnosis of patients with congenital CPHD impacts the clinical follow-up: patients carrying PROPI mutations fail to achieve normal puberty and may develop ACTH deficiency, while those carrying POUIFI mutations present with only GH, TSH, and PRL deficiencies. Furthermore, confirming the diagnosis allows genetic counseling for family members and may contribute to the diagnosis of other affected relatives.

Although several algorithms have been designed to guide candidate gene screening by the Sanger method to identify the molecular etiology of congenital CPHD $(2,37,38)$, mutations have been detected using this approach in only a minority of cases (2). In this context, large-scale sequencing (LSS) is a promising approach that sequences large stretches of DNA base pairs, which may include the entire exome (wholeexome sequencing) or multiple candidate genes (in an LSS panel) in a single sequencing run (39). Due to its capacity to simultaneously screen multiple genes, this method may be especially useful when genotypephenotype correlation is poor or a candidate gene is not suspected (39). Although LSS has great potential for identifying novel genetic causes of rare diseases and expanding the phenotypes associated with known genes, it remains an expensive technique that is not available to all patients. Therefore, in patients with congenital CPHD and topic posterior pituitary who live in areas with a high prevalence of $P R O P I$ mutations such as Brazilian and some Eastern European cohorts, sequencing PROPI using the Sanger method is an adequate first step of a molecular investigation. If no PROPI mutations are found, an LSS panel or wholeexome sequencing could be considered.

\section{CONCLUSIONS}

Since its first description 20 years ago, a large expansion of the phenotypes of patients with PROPI mutations has occurred. In addition to deficiencies in GH, TSH, PRL, and gonadotropins, some patients develop late ACTH deficiency. Therefore, all patients require permanent surveillance. On MRI of patients with PROPI mutations, the pituitary stalk appears intact and the posterior pituitary lobe appears in the normal position, in contrast to the majority of patients with CPHD, who have an interrupted stalk and ectopic posterior pituitary lobe. The anterior lobe in patients with PROPI mutations is usually hypoplastic, but it may be normal or even enlarged and can wax and wane in size. Bi-allelic PROPI mutations are presently the most frequently recognized genetic cause of CPHD worldwide. Here we classified all reported PROPI variants identified to date according to ACMG-AMP guidelines into 29 pathogenic, 2 likely pathogenic, and 2 variants of uncertain significance. The prevalence is higher among offspring of consanguineous parents and familial cases, but sporadic cases can also occur.

Here we summarized the clinical, hormonal, imaging, and genetic characteristics of 14 patients followed at the Hospital das Clinicas of University of Sao Paulo Medical School with 7 different PROPI mutations, the most diverse in a single unit. PROPI mutations are the most frequent cause of autosomal recessive CPHD with topic posterior pituitary lobe.

Acknowledgments: the authors thank Maria Geralda Farah Osorio, Suemi Marui, Peter Kopp, and Maristela Vasconcelos Leite for their contributions to the study.

Funding: this work was supported by the National Council of Technological and Scientific Development - Brazil to BBM (grant number CNPq-PQ 305743/2011-2) and AALJ (grant number CNPq-PQ 304678/2012-0) and by the São Paulo Research Foundation - Fapesp to AALJ (grant number 2013/03236-5).

Disclosure: no potential conflict of interest relevant to this article was reported. 


\section{REFERENCES}

1. Wu W, Cogan JD, Pfaffle RW, Dasen JS, Frisch H, O'Connell SM, et al. Mutations in PROP1 cause familial combined pituitary hormone deficiency. Nat Genet. 1998;18(2):147-9.

2. De Rienzo F, Mellone S, Bellone S, Babu D, Fusco I, Prodam F, et al.; Italian Study Group on Genetics of CPHD. Frequency of genetic defects in combined pituitary hormone deficiency: a systematic review and analysis of a multicentre Italian cohort. Clin Endocrinol (Oxf). 2015;83(6):849-60.

3. Mendonca BB, Osorio MG, Latronico AC, Estefan V, Lo LS, Arnhold IJ. Longitudinal hormonal and pituitary imaging changes in two females with combined pituitary hormone deficiency due to deletion of $A 301, G 302$ in the PROP1 gene. J Clin Endocrinol Metab. 1999;84(3):942-5.

4. Osorio MG, Kopp P, Marui S, Latronico AC, Mendonca BB, Arnhold IJ. Combined pituitary hormone deficiency caused by a novel mutation of a highly conserved residue (F88S) in the homeodomain of PROP-1. J Clin Endocrinol Metab. 2000;85(8):2779-85.

5. Madeira JL, Nishi MY, Nakaguma M, Benedetti AF, Biscotto IP, Fernandes T, et al. Molecular analysis of brazilian patients with combined pituitary hormone deficiency and orthotopic posterior pituitary lobe reveals eight different PROP1 alterations with three novel mutations. Clin Endocrinol (Oxf). 2017;87(6):725-32.

6. Abrão MG, Leite MV, Carvalho LR, Billerbeck AE, Nishi MY, Barbosa AS, et al. Combined pituitary hormone deficiency (CPHD) due to a complete PROP1 deletion. Clin Endocrinol (Oxf). 2006;65(3):294-300.

7. Camper SA, Saunders TL, Katz RW, Reeves RH. The Pit-1 transcription factor gene is a candidate for the murine Snell dwarf mutation. Genomics. 1990;8(3):586-90.

8. Li S, Crenshaw EB, Rawson EJ, Simmons DM, Swanson LW, Rosenfeld MG. Dwarf locus mutants lacking three pituitary cell types result from mutations in the POU-domain gene pit-1. Nature. 1990;347(6293):528-33.

9. Pfäffle RW, DiMattia GE, Parks JS, Brown MR, Wit JM, Jansen M, et al. Mutation of the POU-specific domain of Pit-1 and hypopituitarism without pituitary hypoplasia. Science. 1992;257(5073):111821.

10. Tatsumi K, Miyai K, Notomi T, Kaibe K, Amino N, Mizuno Y, et al. Cretinism with combined hormone deficiency caused by a mutation in the PIT1 gene. Nat Genet. 1992;1(1):56-8.

11. Sornson MW, Wu W, Dasen JS, Flynn SE, Norman DJ, O'Connell $\mathrm{SM}$, et al. Pituitary lineage determination by the Prophet of Pit1 homeodomain factor defective in Ames dwarfism. Nature. 1996;384(6607):327-33.

12. Duquesnoy P, Roy A, Dastot F, Ghali I,Teinturier C, Netchine I, et al. Human Prop-1: cloning, mapping, genomic structure. Mutations in familial combined pituitary hormone deficiency. FEBS Lett. 1998;437(3):216-20.

13. Cogan JD, Wu W, Phillips JA 3rd, Arnhold IJ, Agapito A, Fofanova OV, et al. The PROP1 2-base pair deletion is a common cause of combined pituitary hormone deficiency. J Clin Endocrinol Metab. 1998;83(9):3346-9

14. Deladoëy J, Flück $C$, Büyükgebiz $A$, Kuhlmann BV, Eblé $A$, Hindmarsh PC, et al. "Hot spot" in the PROP1 gene responsible for combined pituitary hormone deficiency. J Clin Endocrinol Metab. 1999;84(5):1645-50.

15. Bottner A, Keller E, Kratzsch J, Stobbe H, Weigel JF, Keller A, et al. PROP1 mutations cause progressive deterioration of anterior pituitary function including adrenal insufficiency: a longitudinal analysis. J Clin Endocrinol Metab. 2004;89(10):5256-65.

16. Lebl J, Vosáhlo J, Pfaeffle RW, Stobbe H, Cerná J, Novotná D, et al. Auxological and endocrine phenotype in a population-based cohort of patients with PROP1 gene defects. Eur J Endocrinol. 2005;153(3):389-96.

17. Flück C, Deladoey J, Rutishauser K, Eblé A, Marti U, Wu W, et al. Phenotypic variability in familial combined pituitary hormone deficiency caused by a PROP1 gene mutation resulting in the substitution of Arg-->Cys at codon 120 (R120C). J Clin Endocrinol Metab. 1998;83(10):3727-34.

18. Navardauskaite R, Dusatkova P, Obermannova B, Pfaeffle RW, Blum WF, Adukauskiene D, et al. High prevalence of PROP1 defects in Lithuania: phenotypic findings in an ethnically homogenous cohort of patients with multiple pituitary hormone deficiency. J Clin Endocrinol Metab. 2014;99(1):299-306.

19. Tenenbaum-RakoverY, Sobrier ML, Amselem S. A novel POU1F1 mutation ( $p$. Thr168llefs X7) associated with an early and severe form of combined pituitary hormone deficiency: functional analysis and follow-up from infancy to adulthood. Clin Endocrinol (Oxf). 2011;75(2):214-9.

20. Pavel ME, Hensen J, Pfäffle R, Hahn EG, Dörr HG. Long-term follow-up of childhood-onset hypopituitarism in patients with the PROP-1 gene mutation. Horm Res. 2003;60(4):168-73.

21. Riepe FG, Partsch CJ, Blankenstein O, Mönig H, Pfäffle RW, Sippell WG. Longitudinal imaging reveals pituitary enlargement preceding hypoplasia in two brothers with combined pituitary hormone deficiency attributable to PROP1 mutation. J Clin Endocrinol Metab. 2001;86(9):4353-7.

22. Pernasetti F, Toledo SP, Vasilyev VV, Hayashida CY, Cogan JD, Ferrari $\mathrm{C}$, et al. Impaired adrenocorticotropin-adrenal axis in combined pituitary hormone deficiency caused by a two-base pair deletion (301-302delAG) in the prophet of Pit-1 gene. J Clin Endocrinol Metab. 2000;85(1):390-7.

23. Asteria C, Oliveira JH, Abucham J, Beck-Peccoz P. Central hypocortisolism as part of combined pituitary hormone deficiency due to mutations of PROP-1 gene. Eur J Endocrinol. 2000;143(3): 347-52.

24. Weaver JU, Thaventhiran L, Noonan K, Burrin JM, Taylor NF, Norman MR, et al. The effect of growth hormone replacement on cortisol metabolism and glucocorticoid sensitivity in hypopituitary adults. Clin Endocrinol (Oxf). 1994;41(5):639-48.

25. Papageorghiou AT, Ohuma EO, Altman DG, Todros T, Cheikh Ismail L, Lambert A, et al.; International Fetal and Newborn Growth Consortium for the 21st Century (INTERGROWTH-21st). International standards for fetal growth based on serial ultrasound measurements: the Fetal Growth Longitudinal Study of the INTERGROWTH-21st Project. Lancet. 2014;384(9946):869-79.

26. Ranke MB, Price DA, Reiter EO. Growth hormone therapy in pediatrics: 20 years of KIGS. Basel/New York: Karger; 2007.

27. Arnhold IJ, Nery M, Brown MR, Voss TC, VanderHeyden TC, Adess ME, et al. Clinical and molecular characterization of a Brazilian patient with Pit-1 deficiency. J Pediatr Endocrinol Metab. 1998;11(5):623-30.

28. Lemos MC, Gomes L, Bastos M, Leite V, Limbert E, Carvalho D, et al. PROP1 gene analysis in Portuguese patients with combined pituitary hormone deficiency. Clin Endocrinol (Oxf). 2006;65(4): 479-85.

29. Nascif SO, Vieira TC, Ramos-Dias JC, Lengyel AM, Abucham J. Waxing and waning of a pituitary mass in a young woman with combined pituitary hormone deficiency (CPHD) due to a PROP-1 mutation. Pituitary. 2006;9(1):47-52.

30. Voutetakis A, Argyropoulou M, Sertedaki A, Livadas S, Xekouki $\mathrm{P}$, Maniati-Christidi $\mathrm{M}$, et al. Pituitary magnetic resonance imaging in 15 patients with Prop1 gene mutations: pituitary enlargement may originate from the intermediate lobe. J Clin Endocrinol Metab. 2004;89(5):2200-6. 
31. Turton JP, Mehta A, Raza J, Woods KS, Tiulpakov A, Cassar J, et al. Mutations within the transcription factor PROP1 are rare in a cohort of patients with sporadic combined pituitary hormone deficiency (CPHD). Clin Endocrinol (Oxf). 2005;63(1):10-8.

32. Ward RD, Raetzman LT, Suh H, Stone BM, Nasonkin IO, Camper SA. Role of PROP1 in pituitary gland growth. Mol Endocrinol. 2005;19(3):698-710.

33. Richards S, Aziz N, Bale S, Bick D, Das S, Gastier-Foster J, et al., Committee ALQA. Standards and guidelines for the interpretation of sequence variants: a joint consensus recommendation of the American College of Medical Genetics and Genomics and the Association for Molecular Pathology. Genet Med. 2015;17(5): 405-24.

34. Olson LE, Tollkuhn J, Scafoglio C, Krones A, Zhang J, Ohgi KA, et al. Homeodomain-mediated beta-catenin-dependent switching events dictate cell-lineage determination. Cell. 2006;125(3): 593-605.

35. Dusatkova P, Pfaffle R, Brown MR, Akulevich N, Arnhold IJ, Kalina MA, et al. Genesis of two most prevalent PROP1 gene variants causing combined pituitary hormone deficiency in 21 populations. Eur J Hum Genet. 2016;24(3):415-20.

36. Krzisnik CK, Kolacio Z, Battelino T, Brown M, Parks JS, Laron Z. The "little people" of the island of Krk - revisited. Etiology of hypopituitarism revealed. J Endocr Genet. 1999;1:9-19.

37. Davis SW, Castinetti F, Carvalho LR, Ellsworth BS, Potok MA, Lyons $\mathrm{RH}$, et al. Molecular mechanisms of pituitary organogenesis: In search of novel regulatory genes. Mol Cell Endocrinol. 2010;323(1):4-19.

38. Bas F, Uyguner ZO, Darendeliler F, Aycan Z, Cetinkaya E, Berberoglu $M$, et al. Molecular analysis of PROP1, POU1F1, LHX3, and HESX1 in Turkish patients with combined pituitary hormone deficiency: a multicenter study. Endocrine. 2015;49(2):479-91.

39. de Bruin C, Dauber A. Insights from exome sequencing for endocrine disorders. Nat Rev Endocrinol. 2015;11(8):455-64.

40. Birla S, Khadgawat R, Jyotsna VP, Jain V, Garg MK, Bhalla AS, et al. Identification of Novel PROP1 and POU1F1 Mutations in Patients with Combined Pituitary Hormone Deficiency. Horm Metab Res. 2016;48(12):822-7.

41. Fofanova O,Takamura N, Kinoshita E, Parks JS, Brown MR, Peterkova VA, et al. Compound heterozygous deletion of the PROP-1 gene in children with combined pituitary hormone deficiency. J Clin Endocrinol Metab. 1998;83(7):2601-4.

42. Tatsumi KI, Kikuchi K, Tsumura K, Amino N. A novel PROP1 gene mutation (157delA) in Japanese siblings with combined anterior pituitary hormone deficiency. Clin Endocrinol (Oxf). 2004;61(5):635-40.

43. Reynaud R, Chadli-Chaieb M, Vallette-Kasic S, Barlier A, Sarles J, Pellegrini-Bouiller I, et al. A familial form of congenital hypopituitarism due to a PROP1 mutation in a large kindred: pheno- typic and in vitro functional studies. J Clin Endocrinol Metab. 2004;89(11):5779-86.

44. Voutetakis A, Maniati-Christidi M, Kanaka-Gantenbein C, Dracopoulou M, Argyropoulou M, Livadas S, et al. Prolonged jaundice and hypothyroidism as the presenting symptoms in a neonate with a novel Prop1 gene mutation (Q83X). Eur J Endocrinol. 2004;150(3):257-64.

45. Vallette-Kasic S, Barlier A, Teinturier C, Diaz A, Manavela M, Berthezène $F$, et al. PROP1 gene screening in patients with multiple pituitary hormone deficiency reveals two sites of hypermutability and a high incidence of corticotroph deficiency. J Clin Endocrinol Metab. 2001;86(9):4529-35.

46. Parks JS, Brown MR, Hurley DL, Phelps CJ, Wajnrajch MP. Heritable disorders of pituitary development. J Clin Endocrinol Metab. 1999;84(12):4362-70.

47. Vieira TC, Dias da Silva MR, Cerutti JM, Brunner E, Borges M, Arnaldi LT, et al. Familial combined pituitary hormone deficiency due to a novel mutation $\mathrm{R} 990$ in the hot spot region of Prophet of Pit-1 presenting as constitutional growth delay. J Clin Endocrinol Metab. 2003;88(1):38-44.

48. Kelberman D, Turton JP, Woods KS, Mehta A, Al-Khawari M, Greening J, et al. Molecular analysis of novel PROP1 mutations associated with combined pituitary hormone deficiency (CPHD). Clin Endocrinol (Oxf). 2009;70(1):96-103.

49. Ogo A, Maruta T, Ide C, Sakai Y, Matoba Y, Hiramatsu S, et al. Recombinant human growth hormone replacement in a Japanese man with a novel PROP1 gene mutation (R112X). Fukuoka Igaku Zasshi. 2011;102(9):277-83.

50. Avbelj Stefanija M, Kotnik P, Bratanic N, Zerjav Tansek M, Bertok $\mathrm{S}$, Bratina N, et al. Novel Mutations in HESX1 and PROP1 Genes in Combined Pituitary Hormone Deficiency. Horm Res Paediatr. 2015;84(3):153-8.

51. Nose O, Tatsumi K, Nakano Y, Amino N. Congenital combined pituitary hormone deficiency attributable to a novel PROP1 mutation (467insT). J Pediatr Endocrinol Metab. 2006;19(4):491-8.

52. Shibahara H, Ikeshita N, Sugiyama Y, Toda K, Yamamoto D, Herningtyas EH, et al. W194XProp1 and S156insTProp1, both of which have intact DNA-binding domain, show a different DNA-binding activity to the Prop1-binding element in human Pit-1 gene. Mol Cell Endocrinol. 2010;323(2):167-71.

53. Reynaud R, Barlier A, Vallette-Kasic S, Saveanu A, Guillet MP, Simonin G, et al. An uncommon phenotype with familial central hypogonadism caused by a novel PROP1 gene mutant truncated in the transactivation domain. J Clin Endocrinol Metab. 2005;90(8):4880-7.

54. Reynaud R, Gueydan M, Saveanu A, Vallette-Kasic S, Enjalbert A, Brue $T$, et al. Genetic screening of combined pituitary hormone deficiency: experience in 195 patients. J Clin Endocrinol Metab. 2006;91(9):3329-36. 